\title{
Stabilization of Expansive Soil Using Chemical Stabilizer with Cement
}

\author{
${ }^{*}$ S. V. Joshi, ${ }^{2}$ E. M. Gonnade \\ ${ }^{1,2}$ Shri Ramdeobaba College of Engineering and Management, Nagpur-440013 \\ Email: joshisv@rknec.edu; gonnadeem@rknec.edu
}

Received: 07th November 2019, Accepted: 31st January 2020, Published: 29th February 2020

\begin{abstract}
This Research work is aimed to evaluate the suitability of slightly alkaline liquid sodium silicate for stabilization of black cotton soil of India. The study also aimed to investigate the effect of applying liquid sodium silicate with ordinary Portland cement on engineering properties of treated soil. The Laboratory testing involved during experimentation are Atterberg limit test, Proctor test, California Bearing Ratio (CBR) test, Swelling test and Unconfined Compressive Strength (UCS) test. The locally available black cotton soil was treated on various combinations of liquid sodium silicate with ordinary Portland cement. The cement was taking $3 \%$ constant and liquid sodium silicate varies $1 \%, 2 \%, 3 \%, 5 \%$ and $7 \%$ of dry weight of Soil. Samples were cured for 4,7,14 and 28 days before testing. It was observed that

(1) CBR and UCS values increases and reduced the swelling properties up to $3 \%$ combination.

(2) Beyond 3\% combination it reduces the strength development and increases the swelling properties.

(3) Curing enhanced strength development from 4 to 28 days. [8]

Findings of the Laboratory investigation imply that good quality materials, dense compaction, longer curing and proper proportion of stabilizer should be applied for Cementious stabilization. Only the liquid sodium silicate is not a suitable stabilizer but it relatively gives encouraging results with combination of 3\% cement by dry weight of soil. The Combination of 3\% liquid sodium silicate with 3\% cement by dry weight of soil was observed to be the best combination for stabilization of expansive soil as black cotton soil.
\end{abstract}

Keywords

Expansive Soil, CBR, UCS, Stabilization, Sodium Silicate

\section{Introduction}

Soils are the naturally occurring and available in bulk which is most economical civil engineering construction material mainly in road construction activities. Soils are, therefore, a critical element influencing the success of road construction project. However, not all naturally available soils suitable for construction. Expansive soil like Black Cotton Soil cause major problems in the design, construction and maintenance of pavements. [1]

The need for wider application of cost effective and environment friendly technologies of soil stabilization as chemical stabilization, to be customised and adopted in current road construction trend in the country. In the context of Indian's geography, pattern of settlement and economic activities; transport plays a vital role in facilitating economic development in particular. Road transport provides the means for the movement of people, Utilisation of land and natural resources, improved agricultural production and marketing and opportunities for sustainable growth of country. Therefore Road Transport system plays a key role as catalyst to meet poverty reduction targets in India.[7]

\section{Need of Research}

As the road transport plays a vital role in Indian economy, however majority of designs, construction and maintenance approaches used in road sector in the country are based on practices and procedures developed in other countries under their conditions. Therefore, Contextual studies are mandatory. In India applying chemical additives for pavement stabilization is not a wide spread practice. However both Traditional and non traditional stabilizers have been introduced and applied to road construction. This study is an attempt to investigate through experimentation the application of Liquid Sodium silicate in combination with traditional stabilizer cement for expansive soil stabilization. [2]

\section{Objectives of Study}

This research work was under taken with the objectives as follows,

1) To check suitability of liquid sodium silicate as chemical stabilizer of soil in combination with cement.

2) To improve the bearing capacity of sub standard sub grade material.

3) To Study the combination of liquid sodium silicate and cement to access the potential improvement in strength and decrease the plasticity of expansive soil

4) To study the response of treated soil through application of chemical additives in extended curing duration from 4 to 28 days.

5) To reduce the swelling pressure and check best and optimum combination of stabilizer materials. 


\section{Conceptual Review of Soil Stabilization}

For replacement of poor quality soil sub grade material by good quality of materials by reducing the thickness of sub grade layers is feasible but it is more expensive, on the other hand with improved technological advances and concerns for depletion of non-renewable resources, improving the properties of soil using chemical additives is gaining the popularity.[3]

Soil stabilization is a process whereby increase strength and stability of the soil is attended mainly by mechanical or chemical means. The most common improvement achieved through stabilization includes better soil gradation, reduction of plasticity index or swelling potential, increase in durability and strength. In wet weather, stabilization may also be used to provide a working platform for construction operations, also known as soil modification. Soil stabilization decreases damage cause by settlement, washing and collapsing of pavement materials.

\section{Methodology}

The subject of stabilization is relatively well researched in different parts of the world. Most of the study focused on evaluating the suitability of chemical additives introduced in the country for expansive sub grade stabilization. As per the experimental studies on expansive soil using lime and cement (cementitious stabilization) by Tesfaye A. (2001, 2003), the conclusions drawn are:

(1) Expansive soil becomes moderately active to inactive base on the amount of lime and cement added.

(2) Swelling pressure of expansive soil decreases with increasing lime, cement and moulding water content.

(3) 4 to $6 \%$ of lime and 9 to $12 \%$ of cement yielded significant improvement on plasticity and swelling properties of expansive soil. [5]

Christopher M. (2005) also investigated the suitability of traditional and non traditional stabilizers. He used the stabilizer as quick lime, hydrated lime, palletized lime, cement, synthetic polymer and magnesium chloride and he has been concluded the following:

(1) Lime and cement stabilizer were more effective than liquid stabilizer in increasing strength.

(2) Liquid stabilizer was ineffective on soils with high moisture content.

(3) Quick and hydrated lime increase workability of soil though did not producing strength as comparable to cement.

Satee J. did a study on effect of aging on stress-stain behaviour of lateritic soil using sodium silicate as a additive for curing period of $0,1,14$, and 28 days were used to evaluate the effect and the research conclude that :

(1) 0.6 molar sodium silicate liquid gives the maximum improvement in strength for all above curing durations.

(2) The improved maximum strength of treated soil observed at 28 days curing period.

In chemical stabilization traditional and non-traditional stabilizers were used.

Traditional stabilizers are traditional lime and other forms of lime, cement stabilization using ordinary Portland cement ( 2 to $10 \%$ of dry weight of soil) and bituminous stabilization (4 to $7 \%$ of dry weight of soil).

Non traditional stabilizers are calcium chlorite, sodium chlorite, and liquid sodium silicate, thermal stabilization including heating and freezing and electrical stabilization using DC current.

\section{Results Based on Laboratory Investigations}

For this research work, the BC soil was collected from the natural source nearby St. Mary School, Jafar Nagar Nagpur. The samples was prepared for the experimental work which involved sun drying, pulverization and sieving of soil through 4.25 micron IS sieve. The improvement in the index properties of the soil were assessed using Atterberg limit test, Shear strength development of soil using unconfined compressive strength (UCS) and California Bearing Ratio (CBR) test. Also swelling index test was conducted. All the above mentioned tests are conducted as per the Standard Test methods recommended by IS codes.[6]

Sodium silicate liquid of 5 molar concentrations was used along with ordinary Portland cement procured from the local market. The various combinations of samples were studied for constant $3 \%$ cement with $1 \%, 2 \%, 3 \%$, $5 \%$ and $7 \%$ sodium silicate liquid by dry weight of soil. A variation of curing duration was 4, 7, 14 and 28 days for CBR and UCS test.[4]

Index properties of soil were determined using Atterberg limit test and swelling test as mentioned in the following Table no.1. 


\begin{tabular}{|l|l|l|l|l|l|l|}
\hline Atterberg limit & $\begin{array}{l}\text { Liquid } \\
\text { Limit } \\
\text { (LL) }\end{array}$ & $\begin{array}{l}\text { Plastic } \\
\text { Limit (PL) }\end{array}$ & $\begin{array}{l}\text { Plastic } \\
\text { Index (PI) }\end{array}$ & $\begin{array}{l}\text { Free Swell } \\
\text { Index }\end{array}$ & $\begin{array}{l}\text { Water } \\
\text { content \% }\end{array}$ & CBR \% \\
\hline Sample: BC soil & 56.50 & 29.10 & 27.40 & 30.00 & 20.02 & 1.17 \\
\hline
\end{tabular}

Table 1: Index Properties of Soil Using Atterberg Limit Test and CBR

Properties of liquid sodium silicate collected from the local market are as mentioned in Table no. 2

\begin{tabular}{|l|c|c|c|}
\hline Color & Specific gravity & pH & Sodium oxide \\
\hline Light olive green & 1.44 & 12.20 & $10.40 \%$ \\
\hline
\end{tabular}

Table 2: Physical and Chemical Properties of Liquid Sodium Silicate

Mixing combination of $\mathrm{BC}$ soil, cement and liquid sodium silicate for testing of sample in laboratories are designated as per the following Table no.3

\begin{tabular}{|l|c|c|c|c|c|}
\hline Designation & I & II & III & IV & V \\
\hline Mixing & $1 \% \mathrm{SS}+3 \%$ & $2 \% \mathrm{SS}+3 \%$ & $3 \% \mathrm{SS}+3 \%$ & $5 \% \mathrm{SS}+3 \%$ & $7 \% \mathrm{SS}+3 \%$ \\
Combination & OPC + BC soil & OPC + BC soil & OPC + BC soil & OPC + BC soil & OPC + BC soil \\
\hline
\end{tabular}

Table 3: Laboratory Samples Mixing Combination

Test Observations, Results and Analysis

1. Atterberg limit test observations are as mentioned in following Table no. 4

\begin{tabular}{|c|c|c|c|c|c|}
\hline Atterberg limit & $\begin{array}{l}\text { Liquid Limit } \\
\text { (LL) }\end{array}$ & $\begin{array}{l}\text { Plastic Limit } \\
\text { (PL) }\end{array}$ & $\begin{array}{l}\text { Plastic Index } \\
\text { (PI) }\end{array}$ & $\begin{array}{l}\text { Free Swell } \\
\text { Index }\end{array}$ & $\begin{array}{l}\text { Water content } \\
\%\end{array}$ \\
\hline Sample: I & 66.50 & 42.46 & 24.04 & 19.50 & 22.44 \\
\hline Sample: II & 56.00 & 35.00 & 21.00 & 15.00 & 20.82 \\
\hline Sample: III & 50.50 & 30.00 & 20.50 & 16.00 & 19.65 \\
\hline Sample: IV & 55.50 & 37.00 & 18.50 & 15.00 & 18.50 \\
\hline Sample: V & 58.50 & 42.59 & 15.91 & 14.00 & 18.00 \\
\hline
\end{tabular}

Table 4: Result of Atterberg Limit Test

2. CBR test results for various mix combinations and various curing periods are as mentioned in following Table no.5

\begin{tabular}{|c|c|c|c|c|c|}
\hline $\begin{array}{l}\text { Mix combinations/ } \\
\text { curing period }\end{array}$ & I & II & III & IV & V \\
\hline 4 days & 2.34 & 2.40 & 2.42 & 1.49 & 1.25 \\
\hline 7 days & 2.56 & 2.71 & 3.24 & 2.98 & 2.80 \\
\hline 14 days & 2.82 & 2.89 & 4.01 & 3.13 & 2.82 \\
\hline 28 days & 3.57 & 3.83 & 5.18 & 3.11 & 2.92 \\
\hline
\end{tabular}

Table 5: Result of CBR Test for Various Mixing Combination

3. UCS test results for various mix combinations and various curing periods are as mentioned in following Table no.6

\begin{tabular}{|c|c|c|c|c|c|}
\hline $\begin{array}{l}\text { Mix combinations/ } \\
\text { curing period }\end{array}$ & I & II & III & IV & V \\
\hline 4 days & 1.52 & 1.84 & 1.89 & 1.43 & 1.04 \\
\hline 7 days & 2.28 & 2.33 & 2.86 & 1.93 & 1.36 \\
\hline 14 days & 2.89 & 2.95 & 3.47 & 2.21 & 2.00 \\
\hline 28 days & 3.39 & 3.57 & 3.95 & 2.70 & 2.40 \\
\hline
\end{tabular}

Table 6: Result of UCS Test for Various Mixing Combination

4. Swelling values in \% (volume change - Time relationship) for BC soil and various mix combinations are as mentioned in following Table no.7

\begin{tabular}{|l|c|c|c|c|c|c|}
\hline Mix combinations & BC soil only & I & II & III & IV & V \\
\hline Swelling in \% & 19.04 & 2.50 & 2.46 & 2.18 & 3.12 & 4.74 \\
\hline
\end{tabular}

Table 7: Swelling Percentage for Various Mixing Combination 


\section{Conclusion}

From this research work done on $\mathrm{BC}$ soil stabilization using various \% of liquid sodium silicate and constant (3\%) cement with $\mathrm{BC}$ soil on the basis dry weight of soil, the following conclusions are drawn.

1. Properties of the soil like plasticity Index, Free Swell Index and water content are reduce with increasing the $\%$ of liquid sodium silicate from 1 to $7 \%$ with constant $3 \%$ cement.

2. From above results, it was observed that the mix combination no. III is the best combination for soil stabilization using liquid sodium silicate.

3. It was also observed that the combination no. I to III show the positive implication on strength development and reduction in swelling of treated $\mathrm{BC}$ soil. The combination numbers IV \& V were not favourable for $\mathrm{BC}$ soil stabilization due to decrees in strength and increase in swelling.

4. It was observed that by increasing the curing period from 4 to 28 days, the strength of treated BC soil increases. Therefore proper curing is mandatory for strength development of cementitious stabilizer technique.

5. From the swelling observations of the sample for various mix combination and $\mathrm{BC}$ soil only, it was observed that swelling value of BC soil is very high and it can be reduced considerably by stabilizing the soil using liquid sodium silicate and cement. The combination no.III was the best combination with respect to swelling property.

\section{References}

1. Dr. K.R.Arora, "Soil Mechanics and Foundation Engineering," standard publisher dist (2009), ISBN-10: 8180141128

2. Ethitahezahu Nigussie, "Evalution of Sodium Silicate and its combination with cement/ lime for soil Stabilization", Thesis of Master of Science.

3. Getinet Aschile, "Stabilization of Potentialy Expansive Soils using an Industry Product RBI grade 81 Chemical", Thesis of Master of Science, Addis Ababa University.

4. IS 2720, Part 16, 1987, "Methods of Test for Soil", Labotory determination of CBR, Second revision.

5. Krishna Reddy, "Engineering properties of Soils Based on laboratory Testing", Department of Civil and Materials Engineering University of Illinois at Chicago August 2002.

6. K.V.Marudwar, P.P.Dahale, A.N.Burile, "Comparative Study of B C Soil Stabilization with RBI grade 81 and Sodium Silicate", International journal of Innovative Research in Science, Engineering and Technology, Volume 2, Feb 2013.

7. Molenaar Road materials Part I, "Cohesive and Non Cohesive Soils and Unbound Granular Materials for Bases and Sub bases in road" lecture notes of University of stellembosch, South Africa ,October 2005.

8. Y.Fang, "foundation Engineering hand book, second edition, chapter 9 of "soil stabilization and grouting" page no $318 \& 324$. 